\title{
Development of Rich Fen on the SE Baltic Coast, Latvia, during the Last 7500 Years, Using Paleoecological Proxies: Implications for Plant Community Development and Paleoclimatic Research
}

\author{
Mariusz Gałka $^{1,2} \cdot$ Liene Aunina $^{3} \cdot$ Kazimierz Tobolski $^{2} \cdot$ Angelica Feurdean $^{4,5}$
}

Received: 31 August 2015 / Accepted: 20 May 2016 / Published online: 1 June 2016

(C) The Author(s) 2016. This article is published with open access at Springerlink.com

\begin{abstract}
We present the paleoecological development of a rich fen located in the dune area on the SE Baltic coast, during the last 7500 years. The Apšuciems Mire hosts rare and endangered plant communities in Europe, such as Schoenus ferrugineus and Cladium mariscus. Analysis at highresolution of plant macroremains in two peat cores was carried out to reconstruct local vegetation succession and fluctuations in moisture availability on the peatland, while a pollen record was developed to reconstruct plant succession, moisture variability and human activity at the regional scale. Based on the presence or the absence of macroremains of plants that occur in wet habitat e.g. Cladium mariscus, Schoenoplectus tabernaemontani, Alisma plantago-aquatica and Botrycoccocus we distinguished four wet periods ca. $6000,2000,1750-1550,1200-150$ cal yr. BP and four dry periods (ca. 7000, 4600-4200, 1800-1750, 1550-1200 cal yr. BP) in the peatland's development. A water level increase at 1200 cal yr. BP triggered the development of plant communities
\end{abstract}

Mariusz Gałka

galka@amu.edu.pl

1 Laboratory of Hydrobiology, Institute of Biology, University of Latvia, 3 Miera Street, Salaspils, LV 2169, Latvia

2 Department of Biogeography and Palaeoecology, (Faculty of Geography and Geology), Adam Mickiewicz University, Dzięgielowa 27, 61-680 Poznań, Poland

3 Laboratory of Geobotany, Institute of Biology, University of Latvia, 3 Miera Street, Salaspils, LV 2169, Latvia

4 Biodiversity and Climate Research Centre (BiK-F), Senckenberg Gesellschaft für Naturforschung Senckenberganlange 25, D-60325 Frankfurt am Main, Germany

5 Romanian Academy Emil Racovită Institute of Speleology, Clinicilor 5, 400006 Cluj Napoca, Romania containing Chara sp., Schoenoplectus tabernaemontani, then Cladium mariscus. Our study shows a link between climate change at the regional scale and vegetation development in Apšuciems Mire. We showed that changes in vegetation structure during last 150 years was caused by drainage and human activity.

Keywords Peatland development $\cdot$ Holocene $\cdot$ Fire activity Cladium mariscus $\cdot$ Climate change $\cdot$ Human impact

\section{Introduction}

Rich fens are one of the most important wetland ecosystems due to their high species-richness and unique species composition (Grootjans et al. 2006). The development of rich fens depends on minerotrophic water; these ecosystems receive nutrients from the soil, rock and groundwater as well as from rainfall. Generally, waterlogged, rich fens are more speciesrich than poor fens and bogs and are mainly dominated by sedges (e.g. Carex, Cladium, Schoenus) and bryophytes (e.g. Campylium, Scorpidium, Calliergonella) (Slack et al. 1980; Rydin et al. 1999; Hájek et al. 2006). Unfortunately, many former fens have been drained and converted for agricultural use (Joosten and Clarke 2002). Presently many of these peatlands are being restored with modern management methods (Keddy 2010; van Diggelen et al. 2015).

Knowledge of the history of rich fens is important for the development of effective management strategies to protect or restore these habitats, as well for prediction of the impact of ongoing climate change on vulnerable plant communities (Pakalne and Kalnina 2005). Presently, in the evaluation of the status of the protected areas, questions such as "what is natural?", "which species are native?" and "how do we protect these ecosystems? "(Feurdean et al. 2009; Willis and Bhagwat 
2010; Lamentowicz et al. 2015) are increasingly being posed. Palaeoecological studies are helpful for understanding the long-term development of protected habitats, thus clarifying the questions mentioned above (Seddon et al. 2014).

Many rich fens in Europe are under protection, but unfortunately, knowledge about their development over centuries or millennia is still poor. In contrast to palaeoecological research, many studies focusing on various aspects of recent rich fens e.g. ecology, distribution of plants and restoration have been carried out (Salmina 2004; van der Hoek et al. 2004; Mälson and Rydin 2007; van Diggelen et al. 2015). Multi-proxy paleoecological studies aiming to reconstruct the development of rich-fens in response to past climatic changes in Europe were conducted at the Stażki rich fen in the lowlands of northern Poland (Lamentowicz et al. 2013) and in Male Bielice, a mountainous area in the Western Carpathians (Hájková et al. 2013). Previous palaeobotanical studies (plant macroremains and pollen) of poor fen peatlands in coastal dune areas in the southern Baltic Sea coast in Poland showed that their development was associated with Baltic Sea level changes (Tobolski 1987). In the eastern part of the Baltic coast, high-resolution analyses of plant macroremains have mainly targeted boreal raised bogs (Sillasoo et al. 2007, 2011; Väliranta et al. 2007) and dealt with postglacial palaeoenvironmental changes including tree migration, climatic events, human impact and peat accumulation (Amon et al. 2010; Ozola et al. 2010; Veski et al. 2012; Kalnina et al. 2015; Stankevica et al. 2015; Stivrins et al. 2016).

For example, Holocene palaeoclimatic reconstructions based on pollen data in Latvia show that summer temperatures during the Holocene Thermal Maximum (HTM, 8000$4000 \mathrm{cal}$ yr. BP) were $2.5^{\circ} \mathrm{C}$ higher than the modern value and that these temperatures were warmer than in Central Europe and Scandinavia (Heikkilä and Seppä 2010). From ca. 4000 to $2600 \mathrm{cal}$ yr. BP a gradual cooling was detected (Heikkilä and Seppä 2010). Palaeoclimatic reconstructions (plant macrofossil data, testate amoebae analysis, peat humification) in the Baltic Sea region (Estonia), documented an increase in bog surface wetness at c. 3100 , $3010,2990,2300,1750,1610,1510,1410,1110,540$ and $310 \mathrm{cal}$ yr. BP, and during four longer periods between $\mathrm{c}$. 3170 and $2850 \mathrm{cal}$ yr. BP, 2450 and $2000 \mathrm{cal} \mathrm{yr}$. BP, 1770 and $1530 \mathrm{cal} \mathrm{yr}$. BP and $880 \mathrm{cal} \mathrm{yr}$. BP to the present. (Sillasoo et al. 2007).

Here, for the first time in this part of Europe, we document the long-term development of a rich fen from the Latvian Baltic coastal dunes over the last ca. 7500 years. Our study is based on high-resolution, contiguous plant macroremains combined with pollen analysis of two cores from Apšuciems Mire. Specifically, we aim to: i) reconstruct the factors that have impacted on the development of rich fen throughout time; ii) define the variability over the last 1200 years in local vegetation development by using two parallel peat cores as replicates; and iii) reconstruct the history of the Cladium mariscus community, the most abundant species in the rich fen. This approach is rarely employed in palaeoecological studies (Lamentowicz et al. 2011; Gałka and Lamentowicz 2014), but it is crucial for validation for paleoenvironmental interpretations, especially for testing the impact of recent climate change on the local vegetation in various parts of peatland (Charman et al. 1999).

A particular concern of our study is Cladium mariscus, which is a rare, endangered, and vulnerable plant in rich fens. Cladium mariscus and the habitat type $7210^{*}$ Calcareous fens with Cladium mariscus are currently subject to legal protection in the European Union and listed on Annex I of the Council Directive on the conservation of natural habitats and of wild fauna and flora. Studies on Cladium mariscus have usually focused on two aspects. Some dealt with the description of its modern environment i.e. Eggers (1994); Salmina (2004); Buczek (2005); Theocharopoulos et al. (2006), whilst others were concerned with its palaeoecology (BalátováTuláćková 1991; Gałka and Tobolski 2011, 2012; Pokorný et al. 2010; Hájková et al. 2013), because it was observed to be a good indicator of climate changes (Berglund 1968; Walter and Straka 1970).

\section{The Study Site}

The study area Apšuciems Mire $\left(57^{\circ} 3^{\prime} \cdot 7.5492 \mathrm{~N}\right.$, $23^{\circ} 19^{\prime \prime} 7.8708 \mathrm{E}$ ) is located on the south-western coast of the Gulf of Riga at the very southern end of the Engure Plain, where the Coastal Lowland is narrow and represented by the Baltic Ice Lake accumulative plain (Fig. 1). This mire has developed in a depression in the coastal area due to the raising of the water level during the Littorina Sea transgression (Kalnina et al. 2012). After the sea basin regression, a long spit of sands formed between Apšuciems Mire and the Gulf of Riga. Initially this occurred as a large underwater bar, which later appeared above water and was covered by parallel dune ridges separating the depression basin from the open sea (Eberhards and Saltupe 2000), reaching up to $8.9 \mathrm{~m}$ a.s.l. The highest elevation of Apšuciems Mire itself reaches a maximum of $6.6 \mathrm{~m}$. The relief at the western margin of Apšuciems Mire was formed under the conditions of the shallow coastal zone of the Baltic Ice Lake, where glaciolimnic sandy sediments with an admixture of pebbles and gravel accumulated closer to the coast (Juškeviès et al. 1999). The lowest layer of the Quaternary deposits is formed by thin (1-2.5 m) Weichselian reddish clayey till with boulders on the top of this layer (Juškeviès et al. 1999). The thickness of the Quaternary deposits (mainly sand and clayey sand) in the study area does not exceed $20 \mathrm{~m}$ and it is underlain by Upper Devonian Amata Formation sandstones. 
Fig. 1 Site location across Central and Western Europe (source: http://pl.wikipedia.org/ w/index.php?title=Plik:Europe topography_map.

png\&filetimestamp $=$ 20080612084157, Author: San Jose; modified) together with location of the sites (black triangle) cited in the text: 1)

Stążki (Lamentowicz et al. 2013),

2) Male Bielice (Hájková et al. 2013), 3) Stążki (Lamentowicz et al. 2011), 4) Gązwa (Gałka and Lamentowicz 2014), 5) Bagno Kusowo (Gałka et al. 2014a), 6) Kluki (Tobolski 1987), Lake Linówek (Gałka et al. 2014b), 8) Lake Burtnieks (Ozola et al. 2010), 9) Lake Raigastvere (Seppä and Poska 2004), 10) Lake Ruila (Seppä and Poska 2004), 11) Mazais Svētiņu bog, Latvia (Stivrins et al. 2014), 12) Lake Kojle (Gałka 2014), 13) Männikjärve bog, Estonia (Sillasoo et al. 2007), 14) Iso Lehmalampi Lake (SarmajaKorjonen 2001), 15) Kłocie Ostrowieckie (Gałka and Tobolski 2011), 16) Valea Mori (Gałka, unpublic data), 17)

Rzecin (Lamentowicz et al. 2015), 18) Bagno Serebryskie (Buczek 2005)

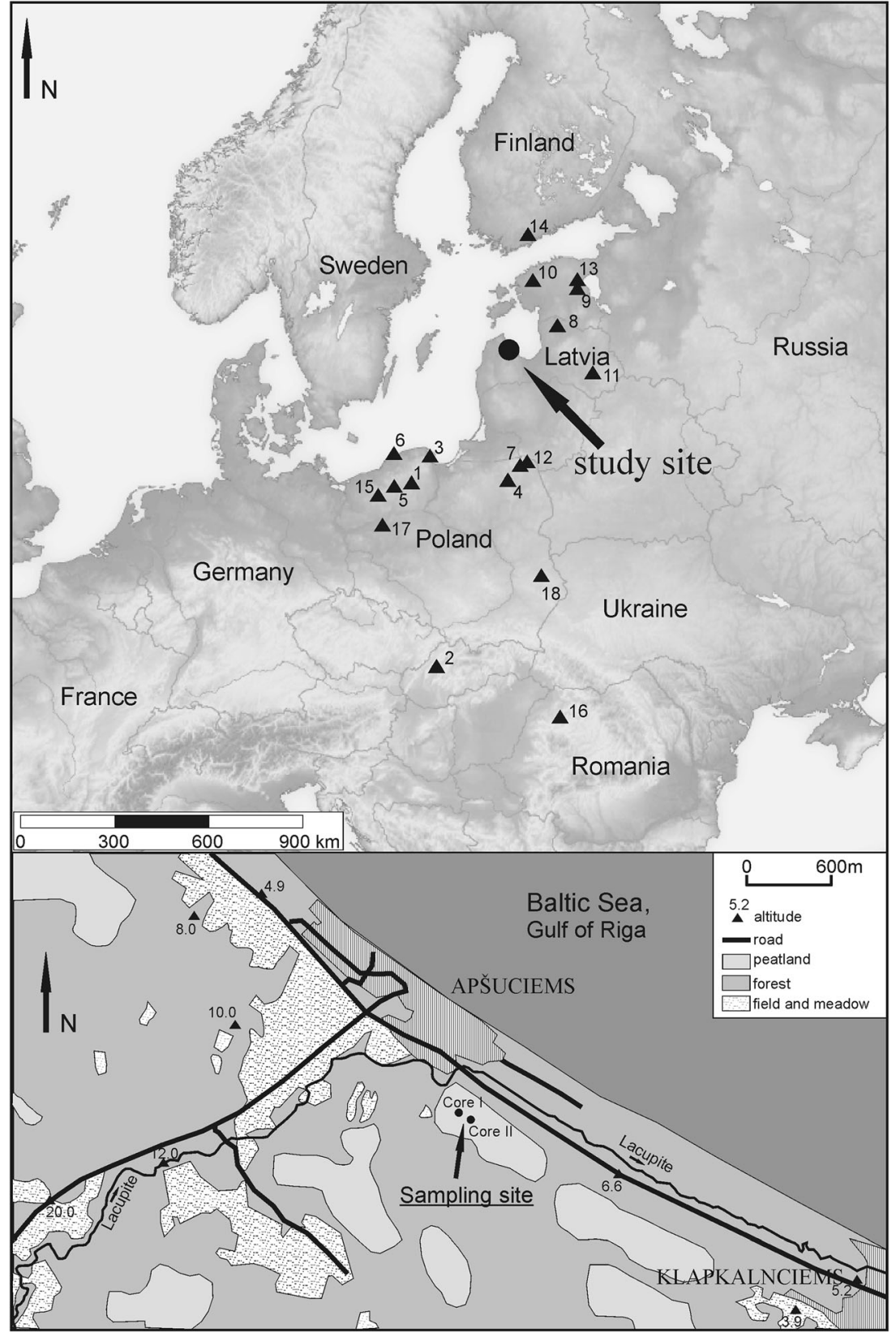

Our study site is under the influence of maritime climate. The mean temperature in the Engure Plain is $-4{ }^{\circ} \mathrm{C}$ in January and $16.5^{\circ} \mathrm{C}$ in July, and mean annual temperature is $6.3{ }^{\circ} \mathrm{C}$. The annual precipitation is $600-700 \mathrm{~mm}$. The frost-free period is 143-160 days (Strautnieks 1995).

The study area Apšuciems Mire is a nature reserve and is included in the Natura 2000 network in Latvia (Natura 2000 code LV0531400). It hosts two habitats of the Habitats Directive Annex I, namely 7230 Alkaline fens and 7210* Calcareous fens with Cladium mariscus and species of the Caricion davallianae (Council of the European Communities 1992).
Apšuciems Mire is part of a peatland that extends 120 ha. The peat cores were retrieved from the open rich fen area (15 ha) surrounded by Pinus sylvestris bog woodland, mixed Pinus sylvestris and Betula pubescens forest as well as wooded dunes with Pinus sylvestris. The Lāčupite River flows through the northern part of the peatland. Surface waters of $20-30 \mathrm{~cm}$ depth characterize the mire in autumn and spring. The open peatland area includes Myrica gale and Schoenus ferrugineus, which dominate rich fen, with dense, scattered Cladium mariscus populations. Other common plant species in the Cladium stands include Carex elata, Carex panicea, and Molinia caerulea. Common associates in the rich fen are 
Schoenoplectus tabernaemontani, Carex panicea, Potentilla erecta, Carex elata, Succisa pratensis, Parnassia palustris, Utricularia intermedia, Primula farinosa and Sesleria caerulea. In the moss layer Campylium stellatum, Scorpidium cossonii, Scorpidium scorpioides and Fissidens adianthoides occur commonly in various amounts. Small hummocks $(5 \times 5 \mathrm{~m})$ with Sphagnum warnstorfii, Sphagnum papillosum and oligotrophic species such as Drosera rotundifolia are occasionally found in the rich fen. Fire scars dated 15-20 years ago are visible on Pinus sylvestris in the south-eastern part of the mire.

\section{Materials and Methods}

\section{Field Work}

Two peat cores were extracted using a Russian-type peat corer from the centre of the Cladium mariscus populations. One complete $235-\mathrm{cm}$ core (APS I) was extracted in the western part and a second $100-\mathrm{cm}$ core (APS II) in the central part of the peatland. The coordinates of the sampling and drilling sites are as follows: Core APS I 57³“14.6591 N, $23^{\circ} 18^{\prime} 56.7612 \mathrm{E}$ and Core APS II 57 $3^{\circ} " 13.94994 \mathrm{~N}$, $23^{\circ} 18^{\prime} 57.0708 \mathrm{E}$. The cores were transported to the laboratory and stored at $4{ }^{\circ} \mathrm{C}$ in a cold room. They were then subsampled in 1-cm intervals for plant macrofossils analysis and at 5-cm intervals for pollen analysis.

In our study, we use the term rich fen in accordance with the European Nature Information System habitat classification (EUNIS, http://www.eunis.eea.europa.eu/) and rich fens are assigned to the type "D4.1. Rich fens, including eutrophic tall-herb fens and calcareous flushes and soaks" (Davies et al. 2004).

The nomenclature of vascular plants follows Gavrilova and Šulcs (1999) while for bryophytes it follows Hill et al. (2006).

\section{Laboratory Work}

\section{Chronology}

Four AMS (Accelerator Mass Spectrometry) radiocarbon dates measured on selected terrestrial plants at the Poznań Radiocarbon Laboratory were used to generate the age-depth for the core APS I. For the APS II core, one AMS date was obtained to define the time of the reappearance of Cladium mariscus as the dominant plant in the upper part of this core and to determine whether this event was synchronous to that from core APS I core (Table 1). The calibration of the radiocarbon dates and the construction of the age-depth were performed with OxCal 4.1 software (Bronk Ramsey 2009) and the IntCal13 curve (Reimer et al. 2013) applying a P_Sequence function with a $\mathrm{k}$ parameter of $1 \mathrm{~cm}^{-1}$ and $1-\mathrm{cm}$ resolution. The most distinct changes in the peat composition, which might be a signal of changes in the peat accumulation rate, were introduced using the "boundary" command (Fig. 2). The modelled age is expressed as calibrated, calendar years before present (cal yr. BP) where present equals $1950 \mathrm{AD}$.

\section{Plant Macrofossils Analysis}

Plant macrofossils were analysed at $1-\mathrm{cm}$ intervals in contiguous samples of approximately $10-12 \mathrm{~cm}^{3}$, totalling of 335 samples. The samples were washed and sieved under a warmwater current using $0.20-\mathrm{mm}$ mesh screens. Initially, the entire sample was analysed with a stereoscopic microscope. In this way, the percentage of individual fossils of vascular plants and brown mosses was obtained. The fossil carpological remains and vegetative fragments (leaves, rootlets, epidermis) were identified using identification keys (Smith 2004; Velichkevich and Zastawniak 2006, 2008) and were compared to recent collection materials. The volume percentages of the different vegetative remains and the mosses were estimated to the nearest $5 \%$ (Gałka et al. 2013; Lamentowicz et al. 2013, 2015; Feurdean et al. 2015). The numbers of seeds, fruits, needles, bud scales and leaves were counted separately. Macroscopic charcoal pieces were also counted during plant macrofossils analysis, and their presence in the sediments provides information of past fire occurrence (Mooney and Tinner 2011; Robin et al. 2013). The volume proportion of amorphous organic matter was estimated during sieving, which serves as a measure of peat decomposition (Gałka et al. 2013). The ecological requirements of several key plant species (Ellenberg et al. 1991; Zarzycki et al. 2002) were used to distinguish wet and dry phases in the peatland development.

\section{Pollen Analysis}

For pollen analysis, samples of $1 \mathrm{~cm}^{3}$ were taken every $5 \mathrm{~cm}$. The sediment samples were treated with $10 \% \mathrm{KOH}$ and then acetolysed following the protocol of Berglund and RalskaJasiewiczowa (1986). 353 (core APS I) and 513 (core APS II) pollen grains of trees, shrubs and upland herbs were counted on average in each sample. No pollen counts are available for the bottom part of core APS II (70-100 cm) and at depth $65 \mathrm{~cm}$ in core APS I, because the grains were heavily corroded. The basis for calculating the pollen percentages is the terrestrial pollen sum. Percentages of pollen and spores of Polypodiaceae and aquatic plants were calculated based on a total sum including terrestrial pollen and their own sums. Pollen indicators of human activity were distinguished according to Behre (1981) and van der Linden and van Geel 
Table 1 Radiocarbon dates from Apšuciems Mire

\begin{tabular}{llllc}
\hline Depth (cm) & Material & Nr. Lab. & $\begin{array}{l}\text { 14C-AMS (y BP) } \\
\text { date }\end{array}$ & $\begin{array}{l}\text { Age cal. yr. BP } \\
(95.4 \%)\end{array}$ \\
\hline APS I 51,5-53,5 & 7 seeds of Cladium mariscus & Poz-70,158 & $1000 \pm 30 \mathrm{BP}$ & $\begin{array}{c}967-799 \\
\text { APS I 112,5 }\end{array}$ \\
2 frag. needles of Picea abies & Poz-73,329 & $1785 \pm 30 \mathrm{BP}$ & $1816-1618$ \\
APS I 163,5-164,5 & Alnus glutinosa cone & Poz-67,828 & $1870 \pm 30 \mathrm{BP}$ & $1877-1724$ \\
APS I 213,5-214,5 & Alnus glutinosa cone & Poz-67,829 & $6090 \pm 40 \mathrm{BP}$ & $7156-6803$ \\
APS II 47-48 cm & 5 seeds of Cladium mariscus & Poz-70,165 & $1170 \pm 30 \mathrm{BP}$ & $1179-985$ \\
\hline
\end{tabular}

(2006) and include pollen types of cultivated field (Cerealiatype, Secale, Triticum-type, Fagophyrum) and the rise in herbaceous pollen types associated with pastures/meadows and ruderals (Plantago lanceolata, Artemisia, Asteraceae, Urtica,
Rumex acetosa-acetosella). The results of pollen, plant macroremains and charcoal records (Figs. 3 and 4), were presented in the form of diagrams drawn with the $\mathrm{C} 2$ graphics program (Juggins 2003).
Fig. 2 Age-depth model of the peat profile Core I in Apšuciems Mire

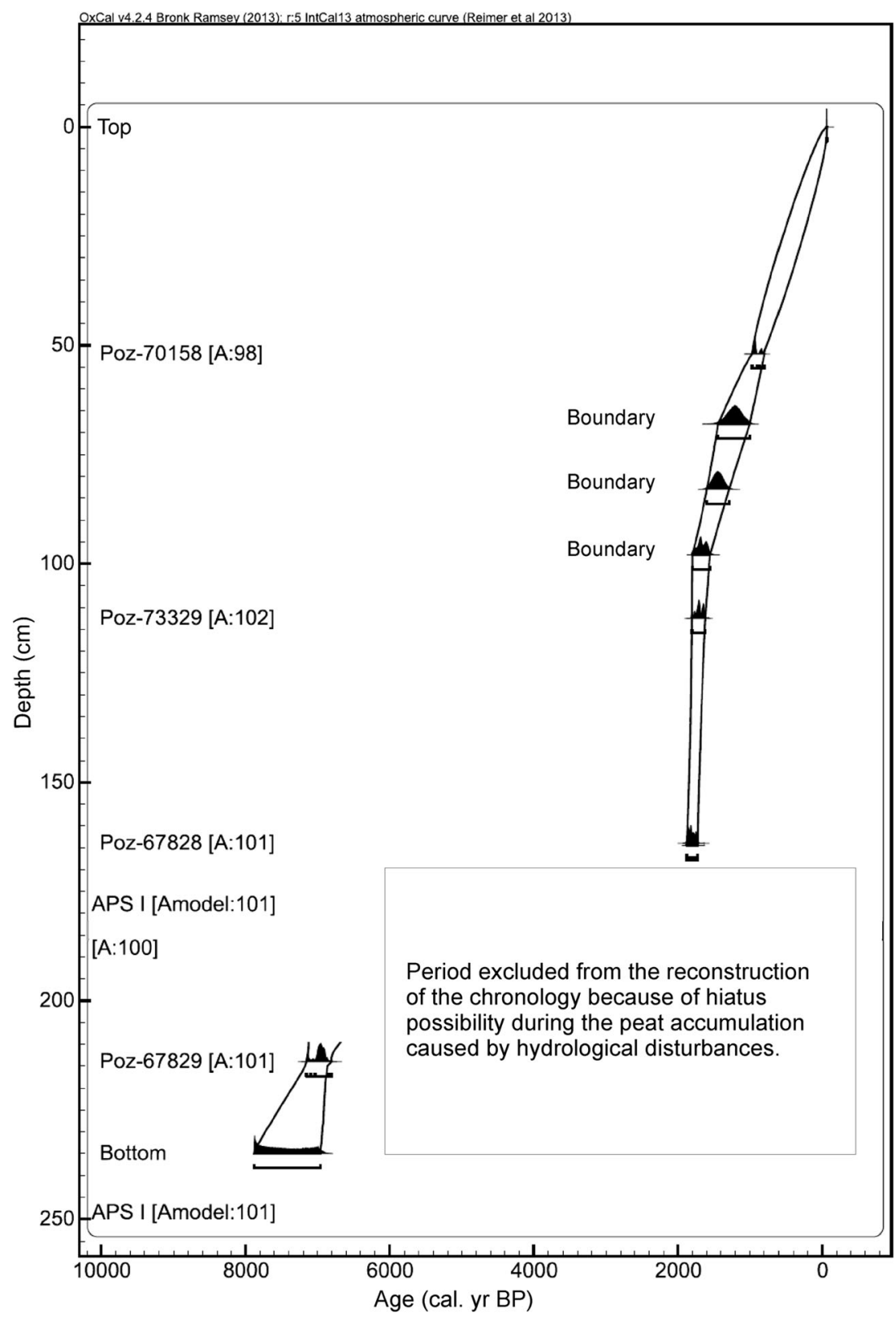




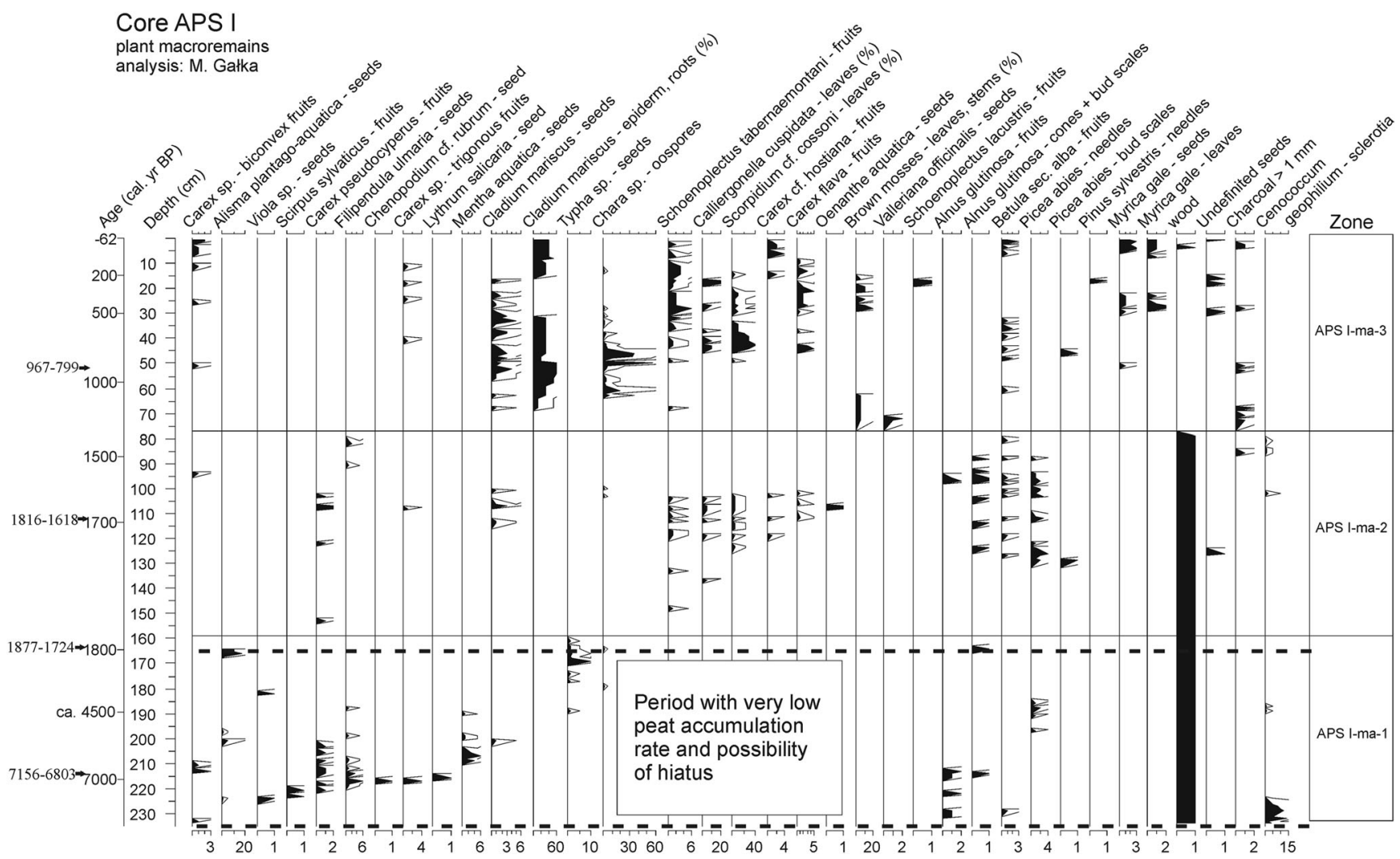

Fig. 3 Plant macrofossils diagram presenting local plant succession in Apšuciems Mire, core I. Taxa with (\%) are estimated volume percentages, others are counts (with X-axis scale labels; note scale differences)

\section{Results}

\section{Chronology and Lithology}

In core APS I, the lowermost part of the sediment (from 235 to $230 \mathrm{~cm}$ ) consists of sand with highly decomposed peat. From 230 to $80 \mathrm{~cm}$, highly decomposed (decomposition up to $80 \%$ ) herbaceous-wood peat developed, with remains of brown mosses (Calliergonella cuspidata and Scorpidium cossoni) between 125 and $105 \mathrm{~cm}$. Moderately decomposed herbaceous peat was found above $80 \mathrm{~cm}$. From $68 \mathrm{~cm}$ Cladium mariscus epidermis roots appeared and from ca. $50 \mathrm{~cm}$ brown mosses were recorded abundantly. In core APS II, highly decomposed herbaceous-wood peat accumulated between 100 and $53 \mathrm{~cm}$. From $53 \mathrm{~cm}$ to the surface of the rich fen herbaceous-brown moss peat developed.

The age-depth model for core APS I was constructed based on four radiocarbon dates (Fig. 2). In the bottom part of the APS I core (235 to $165 \mathrm{~cm})$, the peat accumulation rate was very low and there is also the possibility of hiatuses. However, the radiocarbon age of $6090 \pm 40 \mathrm{BP}$ at depth $214 \mathrm{~cm}$ may prove that the peat accumulation process in Apšuciems Mire started at ca. $7500 \mathrm{cal} \mathrm{yr}$. BP. Therefore, a reliable depth-age model could only be constructed for the top $165 \mathrm{~cm}$ peat layer which accumulated during last 1850 years, with a rate of peat accumulation of $0.88 \mathrm{~mm}$ year $^{-1}$. However, based on the increase of Picea pollen percentages from $5 \%$ at $185 \mathrm{~cm}$ to ca. $20 \%$ at $190 \mathrm{~cm}$ in the core APS I (Fig. 4A) we expect that this peat layer $(185-190 \mathrm{~cm})$ could be accumulated sometimes between 4600 and 4200 cal yr. BP. This is because a massive spread of Picea was documented around this time in the Baltic countries (Stivrins et al. 2014; Kabailienè et al. 2015).

\section{Plant Macrofossils}

Based on the analysis of plant remains, three phases in local vegetation development were visually delimited at Apšuciems Mire: core APS I, western part (Fig. 3).

\section{APS I-ma-1 (235-158 cm), ca. 7500-1800 cal yr. BP}

In the bottom part of this phase Carex pseudocyperus, Filipendula ulmaria and Mentha aquatica were the dominant species. Picea abies needles were found between 184 and $196 \mathrm{~cm}$ and Alnus glutinosa fruits between 210 and $230 \mathrm{~cm}$. Rare occurrences of Cladium mariscus and Scirpus sylvaticus were noted during this phase. In the upper part of this zone an increased abundance of Typha seeds was recorded. 


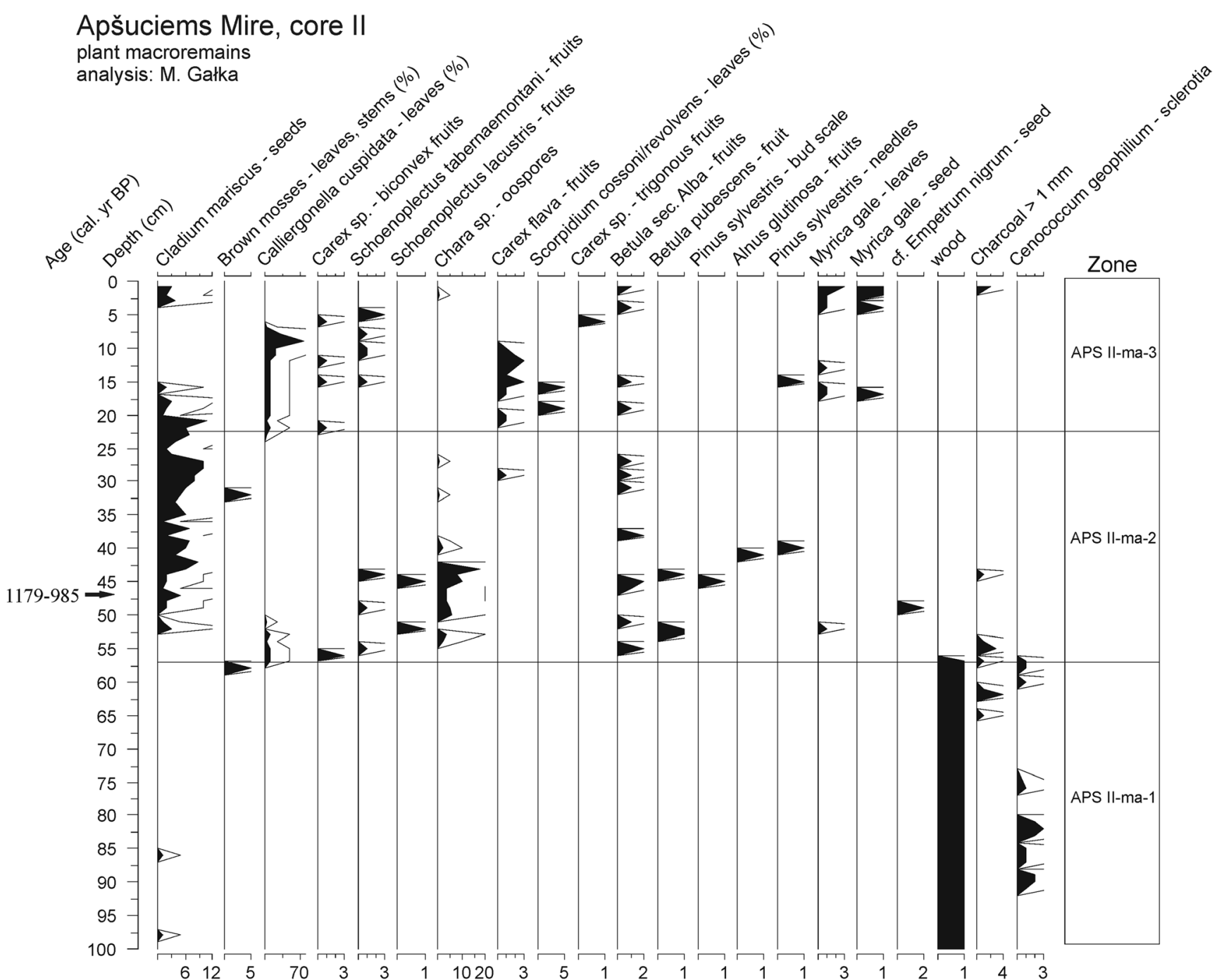

Fig. 4 Plant macrofossils diagram presenting local plant succession in Apšuciems Mire core II. Taxa with (\%) are estimated volume percentages, others are counts (with $\mathrm{X}$-axis scale labels; note scale differences)

APS I-ma-2 (158-77 cm), ca. 1800-1300 cal yr. BP

Abundant occurrence of Carex pseudocyperus and Schoenoplectus tabernaemontani was encountered in this zone, particularly towards the upper part. C. mariscus was present. Among tree species, a few remains of Picea abies, Alnus glutinosa and Betula sec. Alba were found. One charcoal piece was present.

\section{APS I-ma-3 (77-0 cm), ca. 1300- -62 cal yr. BP}

Valleriana officinalis and brown mosses were the dominant plant species in the bottommost part. Numerous seeds of Cladium mariscus, oospores of Chara sp. and fruits of Schoenoplectus tabernaemontani were also recorded. Around $30 \mathrm{~cm}$ and $10 \mathrm{~cm}$ respectively, there was an increase of Myrica gale macroremains. Charcoal pieces (max. piece size ca. $2 \mathrm{~mm}^{3}$ ) were found throughout this period. The abundance and diversity of tree macroremains declined, with only Betula sect. Alba showing a constant presence during this time interval.

Three phases of local vegetation development were visually delimited at core APS II, taken from the central part of the Apšuciems Mire (Fig. 4).

\section{APS II-ma-1 (100-57 cm)}

This zone was poor in plant macrofossil remains, with only a few Cladium mariscus seeds found at 86 and $96 \mathrm{~cm}$.

APS II-ma-2 (57-22 cm)

Numerous seeds of Cladium mariscus and oospores of Chara sp. alongside two species of Schoenoplectus: $S$. lacustris and S. tabernaemontani were recorded in this zone. In the bottom part remains of Calliergonella cuspidata 
were found. Sporadic remains of trees including Pinus sylvestris, Alnus glutinosa and Betula sec. Alba were also recorded throughout this zone. In the upper part macrocharcoal pieces (max. size ca. $2 \mathrm{~mm}^{3}$ ) were found.

APS II-ma-3 $(22-0 \mathrm{~cm})$

Cladium mariscus, Carex flava agg., Schoenoplectus tabernaemontani and Myrica gale were dominant in the upper part of the sediment profile. Calliergonella cuspidata was also present.

One charcoal piece (size ca. $1 \mathrm{~mm}^{3}$ ) in the upper most section was noted.

\section{Pollen Records}

Based on the results of pollen analysis, four phases in regional and local vegetation development were visually delimited at Apšuciems Mire, core APS I (Fig. 5A).

APS I-po-1; 220-192.5 cm, ca. 7500- 4600-4200 cal yr. BP

This zone was characterised by an abundant occurrence of boreal tree taxa including Alnus, Betula, Pinus, and Picea. Temperate tree taxa such as Ulmus, Tilia, Quercus and Corylus avellana also occurred with significant pollen percentages. Among herbaceous plants, there was a high amount of pollen of Poaceae (40 \%), Apiaceae and Rosaceae. Small percentages of anthropogenic indicators, including Cerealia Artemisia, Chenopodiaceae, Rumex acetosa-acetosella and Urtica were also recorded. Pollen of Cyperaceae as well as spores of aquatic plants (Sparganium) and Polypodiales were abundantly recorded in this zone, whereas pollen of Cladium mariscus was found intermittently (Fig. 5).

APS I-po-2; 192.5-122.5 cm, ca. 4600-4200-1750 cal yr. $B P$

Pinus (40 \%) and Picea abies (30\%) became the dominant tree taxa in this zone, however, other boreal taxa such as Alnus $(20 \%)$, and Betula also show conspicuous pollen percentages. Compared to the previous period, the proportion of herbaceous plants, particularly Poaceae, anthropogenic indicators as well as spores of Polypodiales, declined markedly. Cladium mariscus was absent in the first part of this zone but reappeared towards the end of this zone $(140 \mathrm{~cm}$, 1750 cal yr. BP).

APS I-po-3; 122.5-67.5 cm, 1750-1200 cal yr. BP

Pinus (60-70\%) and Picea abies (37 \%) remained the most abundant tree taxa. There was a significant decline in the

\section{Apšuciems Mire}

pollen
analysis: $\mathrm{K}$. Tobolski

A) Core APS I
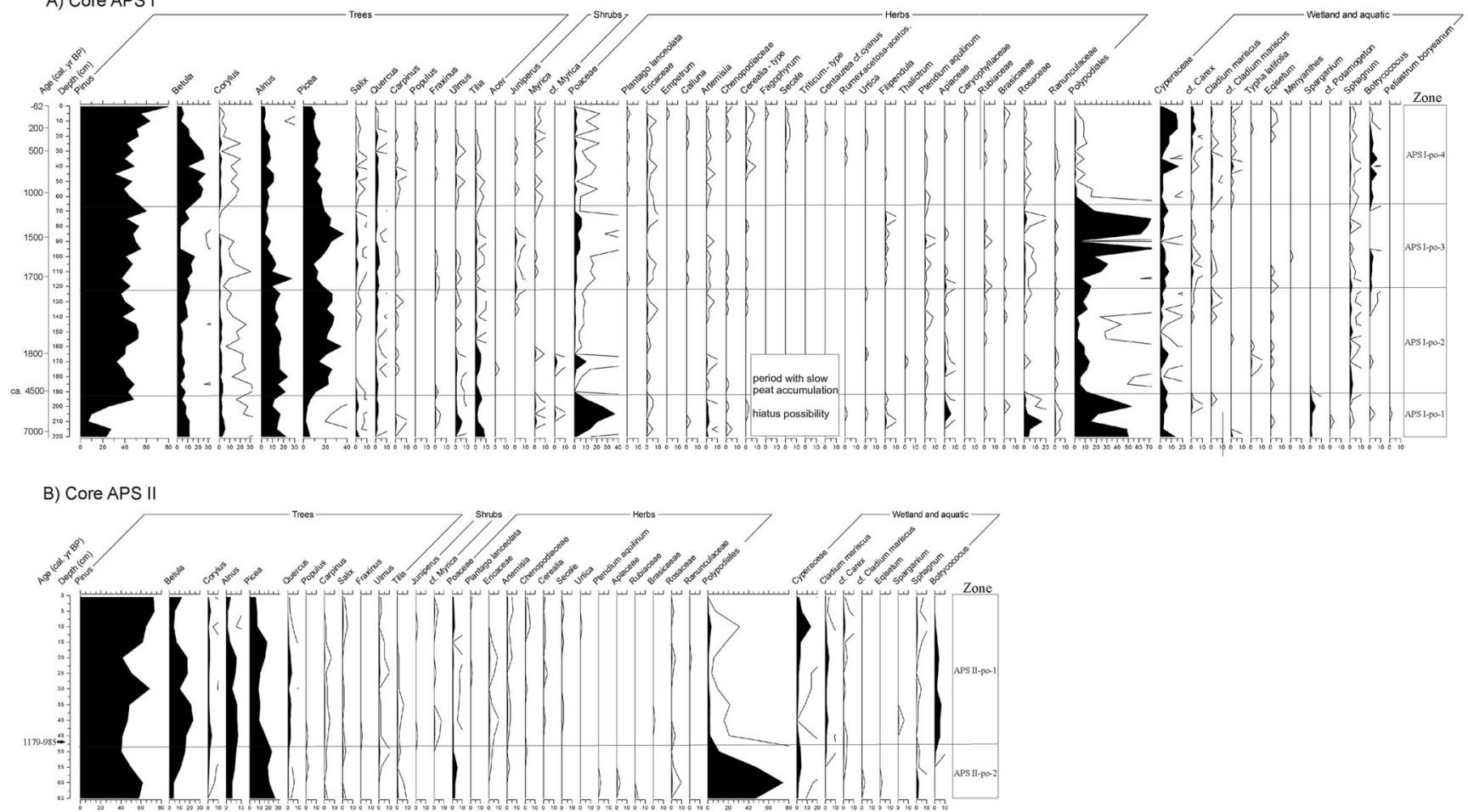

Fig. 5 Pollen, spores and palynomorphs diagram presenting regional and local plant succession in Apšuciems Mire. A core I; (B) core II. Percentages are shown in black, five times exaggeration in grey 
pollen percentages for Alnus, Betula and Corylus, whereas woody taxa that show increased abundances were Quercus, Salix and Juniperus. Among herbaceous communities, Poaceae and Polypodiales became most common and there were also higher frequencies of anthropogenic indicators such as Artemisia, Brassicaceae and cultivated plants (Cerealia). Cladium mariscus was constantly present in this zone (up to $5 \%$ ), whereas most of aquatic taxa disappeared (Fig. 5A).

APS I-po-4; 67.5-0 cm, 1200- -62 cal yr. BP

Pinus maintained its dominance in the forest, and there was also a significant rise in the proportion of Betula, whereas the percentages of other boreal tree taxa i.e., Picea abies and Alnus declined. Temperate taxa (Quercus, Carpinus, Ulmus, Tilia) showed an increased abundance between 1200 and 250 cal yr. BP, but declined markedly thereafter (Fig. 5A). Pollen abundance and diversity of cultivated (Cerealia, Secale, Triticum, Fagopyrum) weeds (Centaurea $\mathrm{cf}$. cyanus), ruderals and grazed (Plantago lanceolata, Chenopodiaceae, Rumex acetosa-acetosella,) fields increased. Polypodiales declined dramatically at the beginning of this zone, while Cyperaceae, Carex and Cladium mariscus and aquatic plants and alga (Botrycoccocus) became more abundant.

Two phases in regional and local vegetation development were visually delimited at Apšuciems Mire, core APS II, central part (Fig. 5B).

APS II-po-1; 65-47.5 cm

The dominant species during this period were Pinus and Picea abies. There was also a high amount of pollen of Poaceae and spores of Polypodiales.

APS II-po-2; 47.5-0 cm

Pinus remained the dominant tree taxa, whereas there was a significant decline in pollen frequencies of Picea abies. Pollen percentages of Betula and Alnus fluctuated markedly. Pollen indicators of human activity such as Secale and Cerealia occurred constantly in this zone. Pollen frequencies of Cyperaceae, Carex and Cladium mariscus and spores of the alga Botrycoccocus increased.

\section{Discussion}

\section{Drivers of Rich Fen Development between ca. 7500 and 1200 Cal Yr. BP}

The following discussion deals with the development of the rich fen based on plant macrofossil and pollen records and the relationship with past climate as a main driver of rich fen development and changes in local hydrological conditions between ca. 7500 and $1200 \mathrm{cal}$ yr. BP. We distinguish four hydro-climatic stages in the development of Apšuciems Mire (Fig. 6).

Hydrological Disturbances (Wet Shifts and Droughts) (APS I 235-137 Cm), ca. 7500-1750 Cal Yr. BP

The Apšuciems Mire developed in a depression in the coastal dune area probably after the position of water level on the mire increased at ca. $7500 \mathrm{cal} \mathrm{yr}$. BP, due to the Littorina Sea transgression. This pattern of a rise in the sea level was previously documented in other parts of the Latvian Baltic Sea coast (Kalnina et al. 2012). The beginning of peat accumulation at 7500 cal yr. BP could be connected with more humid climate conditions in this region, as documented by a higher lake level in mid-European lakes (Magny 2004) and in NE Poland (Gałka et al. 2014b) between 7550 and 7250 cal yr. BP. The first stage in the plant succession was composed of Carex pseudocyperus, Scirpus sylvaticus, and Filipendula ulmaria, species that are typical of lake, pond or river margins (Streeter et al. 2009). The additional occurrence of aquatic plants i.e., Potamogeton and Sparganium could indicate a higher water level than at present (Fig. 6). The appearance of Cladium mariscus (seed and pollen) is recorded at ca. 5000-5500 cal yr. BP (Fig. 6). Cladium mariscus usually occurs in wet habitats such as rush zones of lakes and in pools of calcareous fens (Salmina 2004; Gałka and Tobolski 2012; Hájková et al. 2013). Myrica gale, which is also a wet habitat indicator (Skene et al. 2000), was one of the first plants to grow on the peatland together with Cladium mariscus. Our fossil data are consistent with recent observations of Myrica gale cooccurrence with Cladium mariscus communities (Skene et al. 2000; Salmiña 2003). Both Cladium mariscus and Myrica gale are species with oceanic climate distribution and grow at the eastern limit of their distribution range in $\mathrm{E}$ Europe (Hulten and Fries 1986). However, Myrica gale was found earlier in the fossil records than Cladium mariscus in Latvia i.e. at 11,500-10,200 cal yr. BP, at Lake Burtnieks (Ozola et al. 2010).

The spread of Picea abies sometimes between 4600 and $4200 \mathrm{cal}$ yr. BP is documented by increased of macro-remains and pollen percentages up to $20 \%$ (Fig. 6). A pattern of increasing population size of Picea abies at ca. 4600 4200 cal yr. BP was widely recorded in the Baltic countries e.g., at Lake Raigastvere and Lake Ruila in Estonia (Seppä and Poska 2004), and Mazais Svētinu bog in Latvia (Stivrins et al. 2014) and this was connected with a cooling climate trend after 4500 cal yr. BP (Heikkilä and Seppä 2003; Seppä and Poska 2004). A change towards cooler conditions from ca. 4350 cal yr. BP has been beneficial for the development of Picea abies, and was also detected in north-eastern Poland, where abundant spruce macroremains (needles, bud scales) 


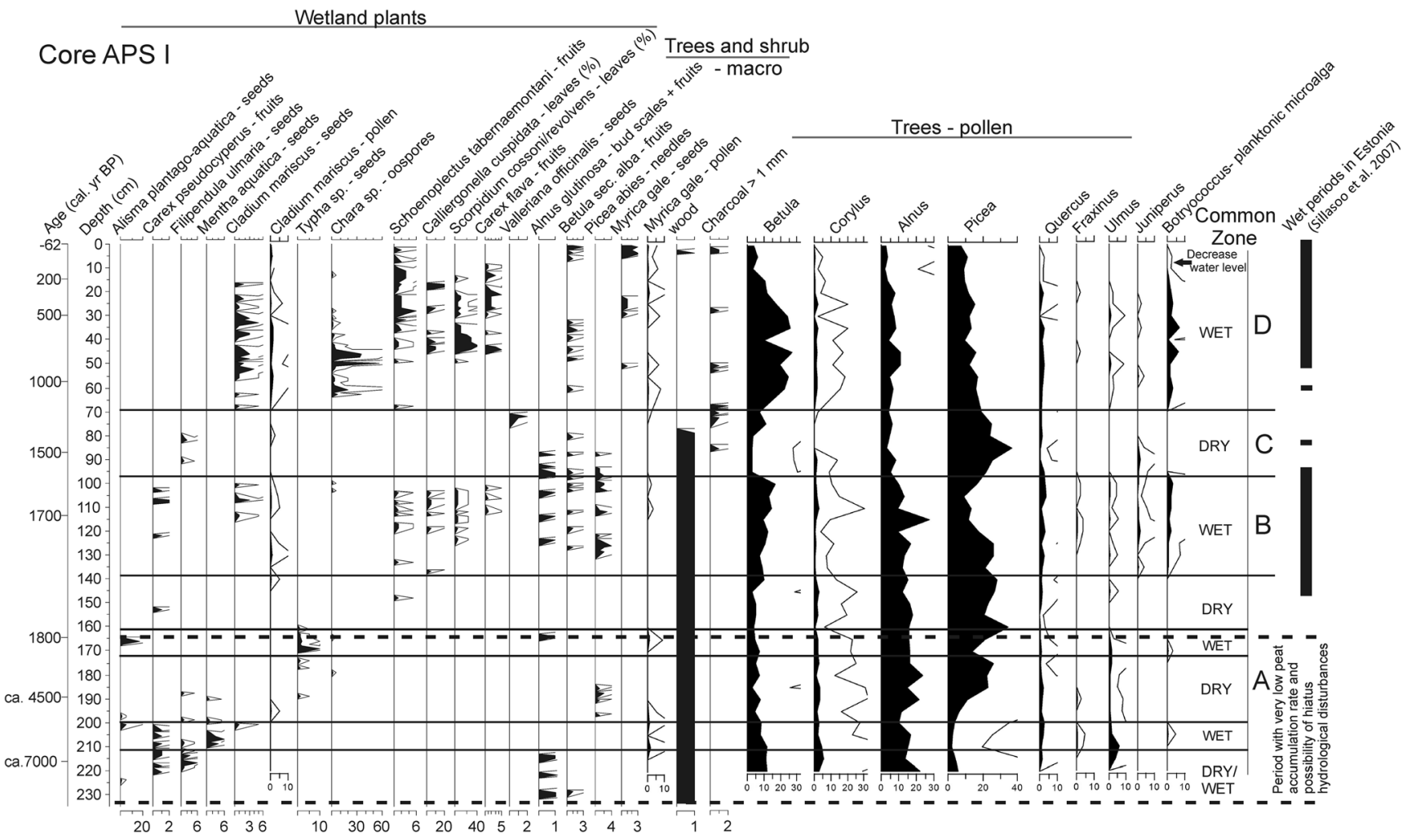

Fig. 6 Comparison of selected curves of palaeobotanical data with climatic events

were found at Lake Linówek and Lake Kojle (Gałka 2014; Gałka et al. 2014b). The accumulation of sand in the core APS I from 188 to $177 \mathrm{~cm}$ (ca. $4500 \mathrm{cal} \mathrm{yr}$. BP), may indicate an increase in wind erosion in the dune area. The decline in frequencies of herbaceous plants and Polypodiales may indicate increased role of trees in local vegetation communities and increase of tree density in forest. Furthermore, the abundant presence of Picea in the forest could have lead to increased soil acidity (Birks 1986), which affected the composition of plant communities.

In the period from 7000 to $4600-4200$ cal yr. BP we noted a thin peat layer (depth 200-212 cm), which accumulated in wet conditions, as documented by the presence of spores of microalga Botrycoccocus, Pediastrum borianum and pollen of Potamogeton (Fig. 5). The occurrence of Cladium mariscus, Mentha aquatica and Alisma plantago-aquatica carpological findings in this layer also support a high water table during this period. However, a low peat accumulation rate between 7000 and $4600-4200 \mathrm{cal}$ yr. BP $(235-190 \mathrm{~cm})$ and the possibility of hiatuses indicate rather dry conditions during this period (Fig. 6). This overall dry period could be linked to the Holocene thermal maximum (HTM), which in NW Europe was characterised by warm and dry conditions (Birks and Seppä 2010; Heikkilä and Seppä 2010). As such a reduced groundwater, lake levels and increase of peat decomposition in peatlands was documented at numerous sites from NW Europe during HTM (Sohar and Kalm 2008; Terasmaa 2011; Berbeco et al. 2012; Edvardsson et al. 2012; Stivrins et al. 2014).

At ca. 1850 cal yr. BP, a temporary increase in the occurrence of planktonic microalgae Botryococcus together with the appearance of Typha angustifolia and Alisma plantagoaquatica in the local plant communities suggest a high water table (Fig 6). Typha angustifolia can grow in deeper water in comparison to Alisma plantago-aquatica, which can also grow on mud (Streeter et al. 2009), whereas the presence of Botryococcus remains in the sediments have been associated with open water and thermal conditions (Kołaczek et al. 2015). We suggest that the blooming of Botryococcus around 1850 cal yr. BP could be connected with a warmer climatic phase of the Roman Period (Büntgen et al. 2011). Our findings of a wet phase at $1850 \mathrm{cal} \mathrm{yr}$. BP are consistent with data presented by Kalnina et al. (2015), who found inter-dune peatlands in the north-western coastal area of Latvia. A higher fen surface wetness at this time was documented in Männikjärve bog (Sillasoo et al. 2007) and in Mazais Svētinu bog (Stivrins et al. 2014).

\section{Wet Stage (APS I 137-98 Cm), ca. 1750-1550 Cal Yr. BP}

The re-appearance of Botrycoccocus, Cladium mariscus and Schoenoplectus tabernaemontani between 1750 and 
$1550 \mathrm{cal} \mathrm{yr}$. BP indicates increased wetness on the Apšuciems Mire. Wet conditions are also suggested by the development of plant communities with Calliergonella cuspidata and Scorpidium cossoni. Both species are typical of wet, mineral-rich habitats and are common in calcareous wetlands or rich fens (Hedenäs 2003). This may be connected to cooler and moister climatic conditions during the Migration Period (Büntgen et al. 2011). This period is marked by distinctive changes in the forest composition such as increased abundance of Betula, decreased of Picea, and the first occurrence of Juniperus populations. Forest disturbances and greater landscape openness at our study site may be connected with human impact as documented by the presence of Cerealia and Plantago lanceolata pollen (Fig. 5). An episodic decline in the abundance of Picea around $1600 \mathrm{cal}$. yr. BP linked to human activity was documented in Mazais Svētinu bog (Stivrins et al. 2014).

\section{Dry Stage (APS I 98-68 Cm, APS II 85-52), ca. 1550-1200 Cal Yr. BP}

The decrease in fen surface moisture between 1550$1200 \mathrm{cal}$ yr. BP is visible in both cores through the disappearance of wet indicators such as Botryococcus, Schoenoplectus tabernaemontani, Cladium mariscus and Chara sp. (Fig. 6). During this time, a massive spread of Polypodiales, probably of Thelypteris palustris, took place. Thelypteris palustris is common in different fen and tall sedge communities, including those with Cladium mariscus (Salmina 2003). This species was noted after hydrological disturbances after fire (Hájková et al. 2012). Support for disturbance by fire at this time is the increase in charcoal abundance as well as changes in the proportion of trees i.e., a decline in Betula, Alnus and an increased in Pinus and Picea abies (Fig. 6). Enhanced local fire activity during this time interval may also indicate decreased moisture availability (Fig. 6). Evidence of a warm and dry climate condition in Europe between 1500 and $1200 \mathrm{cal}$ yr. BP is the low water level in Mid-European lakes (Magny 2004) and Finland (Sarmaja-Korjonen 2001). On the other hand, these changes in forest structure towards a more open character and the presence of macrocharcol could also signal human impact. Evidence of human activity were detected earlier since the Mesolithic in Latvia (Kalnina et al. 2004; Stivrins et al. 2016), but pollen of cultivars (Secale cereale) in this region were only detected around 1500 cal yr. BP (Stivrins et al. 2014). Similarly, the first record of pollen of Secale cereale in NE Poland was around 1500 cal yr. BP (Gałka et al. 2014b), which support the interpretation of increased role of humans on the vegetation composition since ca. $1500 \mathrm{cal} \mathrm{yr}$. BP in this region.

\section{Variability in Local Vegetation Development during Last 1200 Years Based on two Replicated Cores (ii) with Focus on the History of the Cladium mariscus Communities (iii)}

A significant increase of the water level in the Apšuciems Mire can be documented after $1200 \mathrm{cal}$ yr. BP in both cores. Hydrological changes including a rising water table in Apšuciems peatland at $1200 \mathrm{cal}$ yr. BP were visible in pollen record by the decreases abundance of spores of Polypodiales, the appearance of Botrycoccus, increased Cladium mariscus and Myrica gale pollen (Fig. 5). This surface mire conditions likely trigged the development plant communities with Cladium mariscus, Schoenoplectus tabernaemontani, Scorpidium cossonii, and Myrica gale (Figs. 3, 4, and 6, phase D), species that remained abundantly represented in the recent vegetation of the peatland. The presence of Cladium mariscus and Chara sp. in the wettest part of rich fens, spring fens as well as in shallow lakes was also recorded in Poland (Buczek 2005; Gałka and Tobolski 2011, 2012), Latvia (Salmina 2003), and NW Romania (e.g. Valea Mori spring fen, Gałka pers. observation). The presence of a wet climatic phase ca. $1200 \mathrm{cal}$ yr. BP was widely documented in southern Baltic region, N Poland (Lamentowicz et al. 2015) and in N Britain (Charman et al. 2006) and Ireland (Swindles et al. 2013). At ca. $800 \mathrm{cal}$ yr. BP, in APS we found the highest amount of Chara oospores, which may indicate the wettest phase in the development of Apšuciems Mire (Fig. 6). This is because Chara usually occur as a submerged plant (Forsberg 1965). This high water level in Apšuciems Mire coincides with the beginning of wet phase detected in Estonian peatlands (Fig. 6).

In comparison to the recent botanical data on Apšuciems Mire, the disappearance of Carex flava agg. (group) in both cores in the last decades is worth emphasizing. Carex flava agg. includes Carex species such as Carex lepidocarpa, Carex flava, C. demissa, and C. viridula, species growing in moist or wet, often calcareous, habitats (Mossberg and Stenberg 2010), and based on our findings they occurred together with Calliergonella cuspidata. Presently Carex lepidocarpa and Calliergonella cuspidata are common plant species in the base-rich fens of Europe (Jiménez-Alfaro et al. 2013). Both species are still found in Apšuciems Mire, but their abundance has declined markedly over the last century, probably partly due to the expansion of Myrica gale and Cladium mariscus caused by the abandonment of traditional fen management in the 1950's, namely grazing and hay cutting. Grazing reduces shrub density and creates microniches for less competitive plant species (Middleton et al. 2006), whereas hay making prevents Cladium mariscus expansion (Meredith 1985). Cessation of hay making was found to cause the decline of small-sedge communities i.e. changes from Schoenus-Juncetum community to Cladium mariscus 
dominated community in the United Kingdom (Fojt and Harding 1995). Another factor, which may have had a negative impact on Carex lepidocarpa and Calliergonella cuspidata abundance is the change in site hydrology. Topographic maps (1877, 1916, and 1963) show an increasing network of ditches in the surrounding landscape as well as dredging of the Lacupite River. These two factors could have a combined effect on plant species assemblages in fen during the last century. A lowering of the water level during the last 150 years as a result of drainage activity is indicated in Apšuciems Mire and the surrounding area by the decrease in Botryococcus and disappearance of Calliergonella cuspidata and Scorpidium (Fig. 6, phase D). Drier surface conditions are also evidenced by a decline in the abundance of Alnus and Betula, and a corresponding increase in Pinus (Fig. 5A). Local vegetation sensibility and changes in their structure as a response to lowering of the water level caused by drainage and disturbances in forest structure over the last 150 years has been also documented in Stążki fen (Lamentowicz et al. 2013) and Rzecin poor fen (Lamentowicz et al. 2015).

Presently Cladium mariscus is a locally dominant species at two sampling sites. The last fire event on the peatland occurred at ca. 1996-1998, which destroyed the tree layer in the bog woodland and burned part of the rich fen. We found macrocharcoal pieces in two cores, proof of local fire activity in the upper peat layer, but there are no changes in plant communities or of Cladium mariscus associated with this event. Our study shows that peat burnings had a minor effect on the Cladium mariscus population in Apšuciems Mire. Our finding is consistent with those of Buczek (2005), at Bagno Serebryskie, SE Poland (ca. 400 ha), the largest area of Cladium mariscus in this part of Europe, where fire destroyed only the upper part of the plants, allowing the survival and regrowth of the Cladium mariscus culms (Buczek 2005). Pokorný et al. (2010) also reported that short-term disturbances such as burning had a weak effect on Cladium mariscus populations in the Czech Republic. Studies from the southeastern USA, where Cladium jamaicense occurs, confirm that fire can reduce the stand density greatly or kill large stands of Cladium jamaicense, but it does not destroy Cladium populations (Herndon et al. 1991). Experiments conducted by Ponzio et al. (2004) also proved that the Cladium jamaicense population in Florida can survive fires.

\section{Conclusions}

The high-resolution plant macrofossil and pollen record presented here provides the first long-term reconstruction of local vegetation dynamics changes in a rich fen on the southern-eastern Baltic coast, Latvia. The results from our study improve our understanding of the drivers of rich fen development in dune areas. We show that the development of local vegetation at Apšuciems Mire was primarily related to changes in the climate conditions in this region. However, the role of autogenic vegetation succession cannot be fully excluded. The Apšuciems Mire developed in a depression in the coastal dune area probably after the water level increased ca. 7500 cal yr. BP, linked to Littorina Sea transgression and a moister climatic phase. A dry period between 7000 and ca. $4600-4200$ cal yr. BP has slowed the peat accumulation and could be linked to warm and dry climatic conditions of the Holocene thermal maximum. Changes in local vegetation structure over the last 1500 year were caused by palaeohydrological disturbances linked to a combination of climatic changes and human impacts. Drainage of the peatland was conducted during the last 150 years and the consequent lowering of the water level had a negative influence on local vegetation i.e., a decline in Carex flava agg. However, hydrological disturbances during the last millennium have not resulted in major changes in local vegetation in Apšuciems Mire. We also found that plant communities dominated by Cladium mariscus, Schoenoplectus tabernaemontani, and Myrica gale were common in the Apšuciems Mire throughout the last 1000 years and remained common nowadays. This proves that Apšuciems Mire is a close-to-pristine habitat that has hosted rare, presently protected species for hundreds of years. Overall, however, we noticed a more abundant presence of rich fen species during wet periods.

The results of our studies show that palaeoecological methods are reliable tools for the reconstruction of local plant communities' succession in fen. We conclude that it is possible to determine natural reference conditions which can serve later on as the basis for restoration of degraded rich fen habitats.

Acknowledgments Liene Auniņa and Mariusz Gałka received financial support from the European Social Fund Project of Latvia (Project no. 1DP/1.1.1.2.0/13/APIA/VIAA/044). Radiocarbon dating was funded by the National Science Centre (Poland), grant no DEC-2013/09/B/ST10/ 01589 . We are very thankful to Piotr Kołaczek for help in constructing an age-depth model and Laimdota Kalnina for her helpful comments on earlier versions of the manuscript.

Open Access This article is distributed under the terms of the Creative Commons Attribution 4.0 International License (http:// creativecommons.org/licenses/by/4.0/), which permits unrestricted use, distribution, and reproduction in any medium, provided you give appropriate credit to the original author(s) and the source, provide a link to the Creative Commons license, and indicate if changes were made.

\section{References}

Amon L, Heinsalu A, Veski S (2010) Late glacial multiproxy evidence of vegetation development and environmental change at Solova, southeastern Estonia. Est J Earth Sci 59:151-163 
Balátová-Tuláćková E (1991) Das Cladietum marisci. Veröffentlichungen des Geobotanischen institutes der ETH. Stiftung Rübel, Zurich 106: 7-34

Behre K-E (1981) The interpretation of anthropogenic indicators in pollen diagrams. Pollen Spores 23:225-245

Berbeco MR, Melillo JM, Orians CM (2012) Soil warming accelerates decomposition of fine woody debris. Plant Soil 356:405-417

Berglund BE (1968) Late-quaternary vegetation in eastern Blekinge, South-Eastern Sweden. A pollen-analytical study. II. Post-glacial time. Opera Botanica 12:1-190

Berglund BE, Ralska-Jasiewiczowa M (1986) Pollen analysis and pollen diagrams. In: Berglund BE (ed) Handbook of Holocene palaeoecology and palaeohydrology. Wiley \& Sons Ltd, Chichester-Toronto, pp. $455-484$

Birks HJB (1986) Late-quaternary biotic changes in terrestrial and lacustrine environments, with particular reference to north-West Europe. In: Berglund BE (ed) Handbook of Holocene palaeoecology and palaeohydrology. Wiley, Chichester, pp. 3-65

Birks HJB, Seppä H (2010) Late-quaternary palaeoclimatic research in Fennoscandia - a historical review. Boreas 39:655-673

Bronk Ramsey C (2009) Bayesian analysis of radiocarbon dates. Radiocarbon 51:337-360

Buczek A (2005) Habitant conditions, ecology, resources and protection of saw sedge Cladium mariscus (L.) Pohl. in Lublin Macroregion. Acta Agrophysica 9:1-127

Büntgen U, Tegel W, Nicolussi K, McCormick M, Frank D, Trouet V, Kaplan JO, Herzig F, Heussner K-U, Esper J (2011) 2500 years of European climate variability and human susceptibility. Science 331: $578-582$

Charman DJ, Hendon D, Packman S (1999) Multiproxy surface wetness records from replicate cores on an ombrotrophic mire: implications for Holocene palaeoclimate records. J Quat Sci 14:451-463

Charman DJ, Blundell A, Chiverrell RC, Hendon D, Langdon PG (2006) Compilation of non-annually resolved Holocene proxy climate records: stacked Holocene peatland palaeo-water table reconstructions from northern Britain. Quat Sci Rev 25:336-350

Council of the European Communities (1992) Council directive 92/43/ EEC of 21 may 1992 on the conservation of natural habitats and of wild fauna and flora. Off J Eur Communities L206:7-50

Davies CE, Moss D, Hill MO (2004) EUNIS habitat classification (revised 2004). Report to the European Environment Agency. European Topic Centre on Nature Protection and Biodiversity, Paris

Eberhards G, Saltupe B (2000) Geological history, relief and deposits of the Lake Engures (Engure) area along the Baltic Sea. Proc Latv Acad Sci Sect B 54:141-147

Edvardsson J, Linderson H, Rundgern M, Hammarlund D (2012) Holocene peatland development and hydrological variability inferred from bog-pine dendrochronology and peat stratigraphy - a case study from southern Sweden. J Quat Sci 27:553-563

Eggers O (1994) Die norddeutschen Schneidriedvorkommen (Cladium mariscus L.). Botanischer Rundbrief für Mecklenburg-Vorpommern 26:9-24

Ellenberg H, Weber HE, Düll R, Wirth V, Werner W, Paulißen D (1991) Zeigerwerte von Pflanzen in Mitteleuropa. Scr Geol 18:1-248

Feurdean AN, Willis KJ, Astalos C (2009) Legacy of the past land-use changes and management on the 'natural' upland forest composition in the Apuseni Natural Park, Romania. The Holocene 19:967-981

Feurdean A, Gałka M, Kuske E, Tantau I, Lamentowicz M, Florescu G, Liakka J, Hutchinson SM, Mulch A, Hickler T (2015) Last millennium hydroclimate variability in the northern Carpathians (Romania) based on multi-proxy approach. The Holocene 25: 1179-1192

Fojt W, Harding M (1995) Thirty years of change in the vegetation communities of vally mires in Suffolk, England. J Appl Ecol $32: 561-577$
Forsberg C (1965) Environmental conditions of Swedish charophytes. Symbolae Botanicae Upsalienses 18:1-67

Gałka M (2014) Pattern of plant succession from eutrophic lake to ombrotrophic bog in NE Poland over the last 9400 years based on high-resolution macrofossil analysis. Ann Bot Fenn 51:1-21

Gałka M, Lamentowicz M (2014) Sphagnum succession in a Baltic bog in Central-Eastern Europe over the last 6200 years and paleoecology of Sphagnum contortum. Bryologist 117:22-36

Gałka M, Tobolski K (2011) The history of the Cladium mariscus (L.) Pohl. in the "Kłocie Ostrowieckie" reserve (Drawieński National Park). Part I Studia Quaternaria 28:53-59

Gałka M, Tobolski K (2012) Palaeoecological studies on the decline of Cladium mariscus (Cyperaceae) in NE Poland. Ann Bot Fenn 49: 305-318

Gałka M, Miotk-Szpiganowicz G, Goslar T, Jeśśk M, van der Knaap OW, Lamentowicz M (2013) Palaeohydrology, fires and vegetation succession in the southern Baltic during the last 7500 years reconstructed from a raised bog based on multi-proxy data. Palaeogeogr Palaeoclimatol Palaeoecol 370:209-221

Gałka M, Tobolski K, Górska A, Milecka K, Fiałkiewicz-Kozieł B, Lamentowicz M (2014a) Disentangling the drivers for the development of a Baltic bog during the LittleIce Age in northern Poland. Quat Int 328-329:323-337

Gałka M, Tobolski K, Zawisza E, Goslar T (2014b) Postglacial history of vegetation, human activity and lake-level changes at Jezioro Linówek in Northeast Poland, based on multi-proxy data. Vegetation History and Archaeobotany 23:123-152

Gavrilova G̦, Sulcs V (1999) Latvijas vaskulāro augu flora. Taksonu saraksts, Zinātne

Grootjans AP, Adema EB, Bleuten W, Joosten H, Madaras M, Janáková M (2006) Hydrological landscape settings of base-rich fen mires and fen meadows: an overview. Appl Veg Sci 9:175-184

Hájek M, Horsák M, Hájková P, Dítě D (2006) Habitat diversity of central European fens in relation to environmental gradients and an effort to standardise fen terminology in ecological studies. Perspectives in Plant Ecology, Evolution and Systematics 8:97-114

Hájková P, Horsák M, Hájek M, Lacina A, Buchtová H, Pelánková B (2012) Origin and contrasting succession pathways of the western Carpathian calcareous fens revealed by plant and mollusc macrofossils. Boreas 41:690-706

Hájková P, Jamrichova E, Horsak M, Hajek M (2013) Holocene history of a Cladium mariscus-dominated calcareous fen in Slovakia: vegetation stability and landscape development. Preslia 85:289-315

Hedenäs L (2003) The European species of the Calliergon-ScorpidiumDrepanocladus Complex, including some related or similar species. Meylania 28:1-116

Heikkilä M, Seppä H (2003) A 11,000 yr palaeotemperature reconstruction from the southern boreal zone in Finland. Quat Sci Rev 22:541-554

Heikkilä M, Seppä H (2010) Holocene climate dynamics in Latvia, eastern Baltic region: a pollen-based summer temperature reconstruction and regional comparison. Boreas 39:705-719

Herndon A, Gunderson L, Stenberg J (1991) Sawgrass (Cladium jamaicense) survival in a regime of fire and flooding. Wetlands 11:17-28

Hill MO, Bell N, Bruggeman-Nannenga MA, Brugués M, Cano MJ, Enroth J, Flatberg KI, Frahm J-P, Gallego MT, Garilleti R, Guerra J, Hedenäs L, Holyoak DT, Hyvönen J, Ignatov MS, Lara F, Mazimpaka V, Muñoz J, Söderström L (2006) Bryological monograph. An annotated checklist of the mosses of Europe and Macaronesia. J Bryol 28:198-267

Hulten E, Fries M (1986) Atlas of north European vascular plants north of the tropic of cancer, vol 3 vols. Koeltz Scientific Books, Königstein

Jiménez-Alfaro B, Hájek M, Ejrnaes R, Rodwell J, Pawlikowski P, Weeda EJ, Laitinen J, Moen A, Bergamini A, Aunina L, Sekulová L, Tahvanainen T, Gillet F, Jandt U, Dítě D, Hájková P, Corriol G, Kondelin H, Díaz TE (2013) Biogeographic patterns of base-rich fen vegetation across Europe. Appl Veg Sci 17:367-380 
Joosten H and Clarke D (2002) Wise use of mires and peatlands, international mire conservation group and international peat Society, Saarijärvi

Juggins S (2003) C2 User guide. Software for ecological and palaeoecological data analysis and visualisation. University of Newcastle, Newcastle upon Tyne

Juškeviès, V., Mûrnieks, A., Misâns, J. (1999). 42. lapa - Jûrmala. Latvijas ìeoloìiskâ karte [Sheet 42 - Jûrmala. Geological Map of Latvia], Valsts İeoloiijas dienests, Rîga

Kabailienė M, Vaikutienė G, Macijauskaitė L, Rudnickaitė E, Guobytė R, Kisielienė D, Gryguc G, Mažeika J, Motuza G, Šinkūnas P (2015) Lateglacial and Holocene environmental history in the area of Samogitian upland (NW Lithuania). Baltica 28:163-178

Kalnina L, Cerina A, Vasks A (2004) Pollen and plant macro-remain analysis for the reconstruction of environmental changes in the early Metal period. In: Scott E.M., Alekseev A.Yu. \& Zaitseva G. (eds.), Impact of the environment on human migration in Eurasia, Proceedings the NATO Advanced Research Workshop, held in St. Petersburg, 15-18 November 2003, Nato Science Series IV, 42: 275-289

Kalnina L, Cerina A, Ozola I, Grudzinska I, Pujate A, Kuske E (2012) Fen and raised bog development in the areas of former Littorina sea lagoons at the Coastal Lowland of Latvia. Peatlands in Balance. Proceedings of the 14th International Peat congress, Sweden Extended abstract No. 320, pp 1-6

Kalnina L, Stivrins N, Kuske E, Ozola I, Pujate A, Zeimule S, Grudzinska I, Ratniece V (2015) Peat stratigraphy and changes in peat formation during the Holocene in Latvia. Quat Int 383:186-195

Keddy PA (2010) Wetland ecology: principles and conservation, 2nd edn. Cambridge University Press, Cambridge

Kołaczek P, Gałka M, Karpińska-Kołaczek M, Lutyńska M (2015) Late Pleniglacial and late glacial lake-mire transformations in SouthEastern Poland reflected in aquatic and wetland vegetation changes. Quat Int 388:39-50

Lamentowicz M, Gałka M, Pawlyta J, Lamentowicz Ł, Goslar T, MiotkSzpiganowicz G (2011) Climate change and human impact in the soutern Balic during the last millennium reconstructed from an ombrophic bog archive. Studia Quaternaria 28:3-16

Lamentowicz M, Gałka M, Milecka K, Tobolski K, Lamentowicz $Ł$, Fiałkiewicz-Kozieł B, Blaauw M (2013) A 1300 years multi-proxy, high-resolution record from a rich fen in northern Poland: reconstructing hydrology, land-use and climate change. J Quat Sci 28:582-594

Lamentowicz M, Mueller M, Gałka M, Barabach J, Milecka K, Goslar T, Binkowski M (2015) Reconstructing human impact on peatland development during the past 200 years in CE Europe through biotic proxies and X-ray tomography. Quat Int 357:282-294

Magny M (2004) Holocene climate variability as reflected by midEuropean lake-level fluctuations and its probable impact on prehistoric human settlements. Quat Int 113:65-79

Mälson K, Rydin H (2007) The regeneration capabilities of bryophytes for rich fen restoration. Biol Conserv 113:435-442

Meredith TC (1985) Factors affecting recruitment from the seed bank of sedge (Cladium mariscus) dominated communities at Wicken fen, Cambridgehire, England. J Biogeogr 12:463-472

Middleton BA, Holsten BR, van Diggelen R (2006) Biodiversity management of fens and fen meadows by grazing, cutting and burning. Appl Veg Sci 9:307-316

Mooney SD, Tinner W (2011) The analysis of charcoal in peat and organic sediments. Mires and Peat 7: Art. 9. (Online: http://www. mires-and-peat.net/pages/volumes/map07/map0709.php)

Mossberg B, Stenberg L (2010) Den nya nordiska Floran. Bonnier Fakta, Tangen

Ozola I, Ceriņa A, Kalniņa L (2010) Reconstruction of palaeovegetation and sedimentation conditions in the area of ancient Lake Burtnieks, northern Latvia. Est J Earth Sci 59:164-179
Pakalne M, Kalnina L (2005) Mire ecosystems in Latvia. Stapfia 85: $147-174$

Pokorný P, Sáldo J, Bernardowá A (2010) Holocene history of Cladium mariscus (L.) Pohl in the Czech Republic. Implications for species population dynamics and palaeoecology. Acta Palaeobotanica 50: 65-76

Ponzio KJ, Miller SJ, Lee MA (2004) Long-term effects of prescribed fire on Cladium jamaicense Crantz and Typha domingensis pers. Densities. Wetl Ecol Manag 12:123-133

Reimer PJ, Bard E, Bayliss A, Beck JW, Blackwell PG, Bronk Ramsey C, Buck CE, Cheng H, Edwards RL, Friedrich M, Grootes PM, Guilderson TP, Haflidason H, Hajdas I, Hatté C, Heaton TJ, Hoffmann DL, Hogg AG, Hughen KA, Kaiser KF, Kromer B, Manning SW, Niu M, Reimer RW, Richards DA, Scott EM, Southon JR, Staff RA, Turney CSM, van der Plicht J (2013) IntCal13 and Marine13 radiocarbon age calibration curves $0-50,000$ years cal. BP Radiocarbon 55:1869-1887

Robin V, Knapp H, Bork H-R, Nelle O (2013) Complementary use of pedoanthracology and peat macro-charcoal analysis for fire history assessment: illustration from Central Germany. Quat Int 289:78-87

Rydin H, Snoeijs P, Diekmann M (1999) Swedish plant geography. Swedish Society of Plant Geography, Uppsala

Salmina L (2003) The Cladium mariscus (L.) Pohl community in Latvia. Acta Universitatis Latviensis. Earth Environ Sci 654:23-37

Salmina L (2004) Factors influencing distribution of Cladium mariscus in Latvia. Ann Bot Fenn 41:367-371

Sarmaja-Korjonen K (2001) Correlation of fluctuations in cladoceran planktonic: littoral ratio between three cores from a small lake in southern Finland: Holocene water-level changes. The Holocene 11: $53-63$

Seddon AWR, Mackay AW, Baker AG, et al. (2014) Looking forward through the past: identification of 50 priority research questions in palaeoecology. J Ecol 102:256-267

Seppä H, Poska A (2004) Holocene annual mean temperature changes in Estonia and their relationship to solar insolation and atmospheric circulation patterns. Quat Res 61:22-31

Sillasoo Ü, Mauquoy D, Blundell A, Charman D, Blaauw M, Daniell JRG, Toms P, Newberry J, Chambers FM, Karofeld E (2007) Peat multi-proxy data from Männikjärve bog as indicators of late Holocene climate changes in Estonia. Boreas 36:20-37

Sillasoo Ü, Väliranta M, Tuittila E-S (2011) Fire history and vegetation recovery in tworaised bogs at the Baltic Sea. J Veg Sci 22:1084-1093

Skene KR, Sprent JI, Raven JA, Herdman L (2000) Myrica gale L. J Ecol 88:1079-1094

Slack NG, Vitt DH, Horton DG (1980) Vegetation gradients of minerotrophically rich fens in western Alberta. Can J Bot $58: 330-350$

Smith AJE (2004) The Moss Flora of Britain and Ireland. Cambridge University Press, Cambridge

Sohar K, Kalm V (2008) A 12.8-ka-long palaeoenvironmental record revealed by subfossil ostracod data from lacustrine freshwater tufa in Lake Sinijärv, northern Estonia. J Paleolimnol 40:809-821

Stankevica K, Kalnina L, Klavins M, Cerina A, Ustupe L, Kaup E (2015) Reconstruction of the Holocene palaeoenvironmental conditions accordingly to the multiproxy sedimentary records from Lake Pilvelis, Latvia. Quat Int 386:102-115

Stivrins N, Kalnina L, Veski S, Zeimule S (2014) Local and regional Holocene vegetation dynamics at two sites in eastern Latvia. Boreal Environ Res 19:310-322

Stivrins N, Brown A, Veski S, Ratniece V, Heinsalu A, Austin J, Liiv M, Cerina A (2016) Palaeoenvironmental evidence for the impact of the crusades on the local and regional environment of medieval (13th-sixteenth century) northern Latvia, eastern Baltic. The Holocene 26:61-69

Strautnieks I (1995) Engures līdzenums. Latvian daba 2:51-52 
Streeter D, Hart-Davies C, Hardcastle A, Cole F, Harper L (2009) Collins flower guide. The most complete guide to the flowers of Britain and Europe. Collins, London

Swindles GT, Lawson IT, Matthews IP, Blaauw M, Daley TJ, Charman DJ, Roland TP, Plunkett G, Schettler G, Gearey BR, Turner TE, Rea HA, Roe HM, Amesbury MJ, Chambers FM, Holmes J, Mitchell FJG, Blackford J, Blundell A, Branch N, Holmes J, Langdon P, McCarroll J, McDermott F, Oksanen PO, Pritchard O, Stastney P, Stefanini B, Young D, Wheeler J, Becker K, Armit I (2013) Centennial-scale climate change in Ireland during the Holocene. Earth Sci Rev 126:300-320

Terasmaa J (2011) Lake basin development in the Holocene and its impact on the sedimentation dynamics in a small lake (southern Estonia). Est J Earth Sci 60:159-171

Theocharopoulos M, Georgiadis T, Dimitrellos G, Chochliouros S, Tiniakou A (2006) Vegetation types with Cladium mariscus (Cyperaceae) in Greece. Willdenowia 36:247-256

Tobolski K (1987) Holocene vegetational development based on the Kluki reference site in the Gardno-Łeba plan. Acta Palaeobotanica 27:179-222

Väliranta M, Korhola A, Seppä H, Tuittila E-S, Sarmaja-Korjonen K, Laine J, Alm J (2007) High-resolution reconstruction of wetness dynamics in a southern boreal raised bog, Finland, during the late Holocene: a quantitative approach. The Holocene 17:1093-1107

van der Hoek D, van Mierlo AJEM, van Groenendael JM (2004) Nutrient limitation and nutrient-driven shifts in plant species composition in a species-rich fen meadow. J Veg Sci 15:389-396 van der Linden M, van Geel B (2006) Late Holocene climate change and human impact recorded in a south Swedish ombrotrophic peat bog. Palaeogeogr Palaeoclimatol Palaeoecol 240:649-667

van Diggelen JMH, Bense IHM, Brouwer E, Limpens J, van Schie JMM, Smolders AJP, Lamers LPM (2015) Restoration of acidified and eutrophied rich fens: Long-termeffects of traditional management and experimental liming. Ecol Eng 75:208-216

Velichkevich FU, Zastawniak E (2006) Atlas of the Pleistocene vascular plant macrofossils of central and Eastern Europe, part 1: Pteridophytes and monocotyledons. W. Szafer Institute of Botany, Polish Academy of Sciences, Kraków

Velichkevich FU, Zastawniak E (2008) Atlas of the Pleistocene vascular plant macrofossils of Central and Eastern Europe, Part 2: Pteridophytes and monocotyledons.W. Szafer Institute of Botany, Polish Academy of Sciences, Kraków

Veski S, Amon L, Heinsalu A, Reitalu T, Saarse L, Stivrinš N, Vassiljev J (2012) Late-glacial vegetation dynamics in the eastern Baltic region, a complete record since the Bølling (GI-1e). Quat Sci Rev 40:39-53

Walter H, Straka H (1970) Arealkunde. Floristisch-historische Geobotanik, Verlag Eugen Ulmer

Willis KJ, Bhagwat SA (2010) Questions of importance to the conservation of biological diversity: answers from the past. Clim Past 6:759-769

Zarzycki K, Trzcińska-Tacik H, Różański W, Szeląg Z, Wołek J, Korzeniak U (2002) Ecological indicator values of vascular plants of Poland. Biodiversity of Poland, Kraków 